\title{
Law's Entities: Complexity, Plasticity and Justice
}

\section{Introduction}

In the early twenty-first century, and looking beyond it, the landscapes of law's operation are characterised by a growing degree of complexity and pressure. Law is called upon to coordinate relations in a world facing a significant complexities produced by a convergence between biotechnological developments capable of transforming the very conditions of life itself, ${ }^{1}$ climatechange pressures and the threat of the collapse of bio-diversity and eco-systems, and intensifying global inter-dependencies deepening vulnerability on a whole set of scales and measures. ${ }^{2}$

Law itself is a dominant sphere of social coordination within and through which patterns of complexity and inter-dependence emerge. Increasingly dense regulatory networks and interpermeations at all levels between systems and sub-systems of juridical norms in the context of globalisation infinitely complicate past assumptions concerning the very conceptual possibility of drawing clean legal boundaries - and render, as Twining has argued - the standard and somewhat 'black-box' assumptions of traditional jurisprudence inapt. ${ }^{3}$ An almost dizzying range of factors are now understood to generate or multiply legal relations or, minimally, as being 'relevant to analysis of patterns of legal and law-related relations in the modern world'. ${ }^{4}$ Neat systemic delineations - even those traditionally conceived of as internal to law, such as clean 'boundaries' between systems of legal norms - are now extensively problematised by legal interpenetrations ('inter-legalities' ${ }^{5}$ ), law's multiple scenes and contexts and heterogeneity. ${ }^{6}$ Such complex, hybrid and diverse juridical patterns form an analogue to the structural complexities visible in biotechnological developments, in new hybridities and the numerous contemporary theoretical and practical manifestations of heterogeneity, multiplicity and complexity emerging in a range of disciplines, including cybernetics, techno-theory, post-humanism and ecology. ${ }^{7}$

- The author would like to the following: Sean Coyle for his comments on a draft version of this article; Andreas Philippopoulos-Mihalopoulos; various participants at staff seminars held at the Universities of York, Bristol and Exeter in the UK; Emory University in the US, and the Universities of Otago and Waikato in New Zealand; Ngaire Naffine; the anonymous referees of this journal; Bristol Law School, UWE for the grant of some time to reflect on themes and issues invoked by this article, and Chris Jones for research assistance.

${ }^{1}$ RG Lee, 'Look at Mother Nature on the Run in the Twenty-First Century: Responsibility, Research and Innovation' (2012) 1/1 Transnational Environmental Law 105-117.

${ }^{2} \mathrm{P}$ Kirby, Vulnerability and Violence: The Impact of Globalisation (London, Ann Arbor: Pluto Press, 2006).

${ }^{3}$ W Twining, Globalisation and Legal Theory (London: Butterworths, 2000) at 9.

${ }^{4}$ Ibid.

5 '[T]he conception of different legal spaces superimposed, interpenetrated, and mixed in our minds, as much as in our actions .... We live in a time of porous legality or legal porosity, multiple networks of legal orders forcing us to constant transitions and trespassings. Our legal life is constituted by the intersection of different legal orders, that is, by interlegality.': B De Sousa Santos, Toward a New Common Sense:

Law, Science and Politics in Paradigmatic Transition (London: Routledge, 1995), 472-3.

${ }^{6}$ The multiple contexts of law have been termed 'polycontexturality': Teubner attributes this G Gotthard, 'Life as Poly-Contexturality', G Gunther (ed), Beiträge zur Grundlegung einer operationsfahigen Dialektik 1 (Hamburg: Meier, 1976) in G Teubner, 'After Privatisation? The Many Autonomies of Private Law' (1998) 51 Current Legal Problems 393-424. On the 'scenes' of law and multiplicity see A Hirvonen (ed), Polycentricity: The Multiple Scenes of Law (London: Pluto Press, 1998).

${ }^{7}$ For a particularly illuminating discussion of this in the environmental context, see A PhillipopoulosMihalopoulos, Law and Ecology: New Environmental Foundations (London: Glasshouse, 2011). 
This burgeoning complexity directly impinges upon reflections concerning legal personhood, for it is precisely in their light and in response to a growing awareness of their potential implications, along with deepening concerns over climate change, animal suffering and widespread ecological degradation that the subject of law's subject has become a topic of growing contemporary concern. ${ }^{8}$ The present reflection is but one contingent contribution to a broadening debate concerning the extension of legal standing, legal personhood and legal rights subjectivity to a growing range of putative beneficiaries and claimants, ranging from non-human animals; to entire species; to trees; to the climate itself and to post-human entities such as artificial intelligences and robots. ${ }^{9}$

The larger project to which this reflection is devoted demands, arguably, the construction of a general theory of legal subjectivity possessing the plasticity and responsiveness required by contemporary developments and challenges. While an important element of such a general theory of legal subjectivity will be the provision of a theoretically consistent justificatory foundation for the extension of legal subjectivity to putative new candidates, ${ }^{10}$ this article focuses primarily upon the theoretical question of the form of legal subjectivity - a vital, frequently overlooked subject ${ }^{11}$ with decisively important implications. ${ }^{12}$ The argument to be offered here builds upon Naffine's 2003 analysis of the existing available constructs of law's subject, ${ }^{13}$ nuancing it in order to explore how legal subjectivity can be constructed so as to be theoretically flexible enough to respond to complexity and to include a wide (and possibly unpredictable) range of putative claimants. Simultaneously, this account emphasises the importance of drawing attention to the limitations of legal subjectivity in such a way as to extend better protection to those people and beings systematically disadvantaged by its currently dominant form.

The exploration here will take the following structure: some preliminary clarifications and general notes will be offered concerning the terminology of law's 'persons'. This will be followed by the introduction and development of Naffine's three templates of legal personhood, supplemented by fuller theorisation and argument. Finally, conclusions will be offered concerning the utility and

\footnotetext{
${ }^{8}$ Consider, for example of the growing popular resonance of such concerns, the BBC Radio 4 programme, Law in Action, broadcast on Tuesday $20^{\text {th }}$ January 2009, featuring a discussion on 'whether human rights might extend beyond humans, asking whether rights exist for animals, the environment and even robots'. The presenter was joined by writer Kenan Malik, philosopher Jo Woolf and lawyer Christopher Stone, as well as featuring arguments put forward by Peter Singer and Cormac Cullinan. $\langle$ http://www.bbc.co.uk/programmes/b00h42rr> (date of last access: 26/04/2012).

${ }^{9}$ For examples of an increasing and extensive literature, see: P Cavalieri, The Animal Question: Why Nonhuman Animals Deserve Human Rights (New York: Oxford University Press, 2001); C Cohen and T Regan, The Animal Rights Debate (Lanham, MD: Rowman and Littlefield, 2001); CR Sunstein and M Nussbaum (eds), Animal Rights: Current Debates and New Directions (New York: Oxford University Press, 2004); CD Stone, Should Trees Have Standing? Law, Morality and the Environment ( ${ }^{\text {rd }}$ Edn) (Oxford: OUP, 2010); A Grear (ed), Should Trees Have Standing? 40 Years On (Cheltenham: Edward Elgar, 2012); LB Solum, 'Legal Personhood for Artificial Intelligences' (1992) 70 North Carolina Law Review 1231; G Teubner, 'Rights of Non-Humans? Electronic Agents and Animals as New Actors in Politics and Law' (2006) 33 Journal of Law and Society 497.

${ }^{10}$ Berg has offered an initial suggestion for such a justificatory framework: J Berg, 'Of Elephants and Embryos: A Proposed Framework for Legal Personhood' (2007) 59 Hastings Law Journal 369

${ }^{11}$ See Berg, above n 10 at 370; J Dewey, 'The Historic Background of Corporate Legal Personality' (1926) 35 Yale Law Journal 655, at 660; Harvard Note (2001) 'Notes: What We Talk About When We Talk About Persons: The Language of a Legal Fiction' 114 Harvard Law Review 1746.

${ }^{12}$ See, for example, J MacLean, 'The Transnational Corporation in History: Lessons for Today?' (2004) 79 Indiana Law Journal 363.

${ }^{13}$ N Naffine, 'Who Are Law's Persons? From Cheshire Cats to Responsible Subjects' (2003) 66 Modern Law Review 346.
} 
promise of seeing the legal subject as an explicit (and explicitly limited) constructus, which highlights law's limits and the inadequacy its constructs to the complex, organic, shifting, embodied, mutable and situated affectability of the socio-material and spatio-temporal aliveness woven through, beyond and beneath law's systemic closures. This simultaneity of attentiveness is fundamental it is suggested to the production of a theory of legal personhood responsive to the complex challenges and socio-material urgencies of the $21^{\text {st }}$ century and beyond.

\section{Law's Persons}

\section{Some preliminary terminological clarifications ${ }^{14}$}

In theoretical discussions of legal subjectivity different terms are used, sometimes even interchangeably. Writers variously refer to legal persons, legal personality, legal subjects (and subjectivity) and legal entities. Accordingly, it will be of some assistance to draw some preliminary distinctions between these terms, and to indicate which terminology will be preferred here.

As a preliminary matter, we should note that whilst in mainstream legal theory and doctrine the term 'legal person' is generally taken to refer to the corporation and the term 'natural person' to refer to the human being, there is a broad sense in which the term 'legal person' also has a more generic inference and can also be taken to mean something like 'law's person $/ \mathrm{s}^{\prime 15}$ - a category which includes law's 'natural person'. Moreover, the term 'person' has almost inseparable links with the idea of the human person and related theories of human personality. Indeed, on some accounts there is virtually an overlap between law's 'person' and a notion of humanity, and within mainstream legal doctrine the so-called 'natural person' of law is without exception considered to be of human genetic origin. ${ }^{16}$ (In this sense it is perhaps more accurately described as the human legal person'.)

The considerable degree of convergence between the language and concepts of personhood and of humanity exerts considerable semantic traction, even upon the term 'legal person' notwithstanding its deployment within mainstream legal doctrine to refer (predominantly) to the corporation. Even in the field of corporate personality theory, this anthropomorphic tendency is lamented for its obfuscating effects and the confusion generated. ${ }^{17}$ The anthropomorphic traction exerted by the concept and language of the 'person' and its inferences also explains, to a significant extent, attempts to incorporate non-human animal rights claims within a general appeal to 'human rights', ${ }^{18}$ and is further implicated in the development of 'corporate human rights' discourse and the emergence of 'corporate legal humanity'. ${ }^{19}$

\footnotetext{
${ }^{14}$ This section draws upon and develops earlier work in A Grear, Redirecting Human Rights: Facing the Challenge of Corporate Legal Humanity (Basingstoke: Palgrave MacMillan, 2010).

${ }^{15}$ Naffine, above $\mathrm{n} 13$ deploys this terminology.

${ }^{16}$ Berg, above n 10 at 373.

${ }^{17}$ See, eg, N James, 'Separate Legal Personality; Legal Reality and Metaphor' (1993) 5 Bond Law Review 217.

${ }^{18}$ The most well-known example being the Great Apes Project, and represents the underlying logic of the World Declaration on Great Primates. See http://www.greatapeproject.org (date of last access: $30^{\text {th }}$ April 2012).

${ }^{19}$ See Grear, above n 14.
} 
A range of terms are deployed in theoretical discussions of legal subjectivity, in varying ways. Some writers use the terms 'legal person' and 'legal personality' interchangeably. Others draw a distinction between them. Derham, for example, distinguishes between 'the constant unit in the logic of a legal system' (the rights-bearing-unit designated as 'person') and 'legal personality as referring to the sum total of the legal relations, actual or potential, of a legal person' ${ }^{20}$ Accordingly, legal persons can be understood to possess differing legal personalities - a distinction which, moreover, renders intelligible the idea of varying 'categories' of legal person. The term 'legal subject' also has more than one referent. Some writers use the term to indicate the kind of subject or subjectivity constructed by law (in terms, say, of its putative 'rationality', or other characteristics, such as wilfulness or acquisitiveness). ${ }^{21}$ Other writers simply use it as the semantic equivalent of the term 'person'. Nekam, for example, deploys the term 'legal subject' to mean simply a unit (whether a plant, an animal, a human being, a spirit, or a group) regarded as important enough to merit juridical protection and thus to be the subject of legal rights ${ }^{22}-$ a definition which renders the 'legal subject' coterminous with the 'legal person' and constituted by the bearing of legal rights. While the legal subject and legal rights presuppose one another, ${ }^{23}$ the substantive content of this relationship is also prone to various alternate readings depending upon the theoretical framework deployed. For the kind of account that Nekam offers, the subject-of-rights character of a thing says nothing about its intrinsic or subtending qualities, whereas for others, the notion of a rights-bearer inevitably implies inherent characteristics, such as rationality, dignity or autonomy - and above all, for some theorists, humanity.

For the purpose of the argument to follow, I will generally deploy Nekam's preferred terminology of the 'legal entity', and will defend a related conception of the legal subject which moves legal subjectivity away from concepts of personhood towards a more agnostic, formal construct functioning as a system referent. It is worth pointing out some advantages of the terminological choice just indicated, some of which foreshadow arguments in support of the theoretical choice to be defended in this article. First, the term 'legal entity' has an advantage over the term 'legal person' in so far as it suggests a semantic aperture arresting - as it were - the inevitability of the convergence between legal subjectivity and humanity, thus usefully applying a semantic brake to the anthropomorphism haunting discussions of law's persons. Secondly, the agnosticism of the term 'entity' has particular utility in semiotic terms because it also readily implies a gap between 'law's entity' and any particular underlying something - whether that something is primarily conceived of as a being, an entity, a system or a construct. Thirdly, the terminology makes explicit the inescapably and inherently constructed nature of the rights-bearing unit of law. Fourthly, the term 'entity' avoids any intrinsic suggestion of subjectivity in the sense of a self-reflective consciousness and/or other incidents taken to constitute the modern notion of the subject/ person (whether human, animal or intelligent machine) more broadly understood. Fifthly, and perhaps more obliquely, the term

\footnotetext{
${ }^{20}$ D.P Derham, 'Theories of Legal Personality' in L.C Webb (ed) Legal Personality and Political Pluralism (New York: Cambridge University Press, 1958) at 7, adopting a distinction drawn by A. Kocourek, Jural Relations (Indianapolis: Bobbs-Merrill, 1928) at 291-2.

${ }^{21}$ Such a meaning is quite common, for example, in critical legal theoretical discourse drawing on Foucauldian and/or Feminist notions of the construction of the subject.

${ }^{22}$ A Nekam, The Personality Conception of the Legal Entity (Boston: Harvard University Press, 1938) at 26.

${ }^{23}$ C Douzinas, The End of Human Rights (Oxford: Hart, 2000) at 233.
} 
'entity', depending upon its deployment, suggests the important distinction, often overlooked, between legal rights and moral rights, legal personhood and moral personhood. ${ }^{24}$

\section{Some general notes on the existing theoretical approaches}

It will be helpful in developing the argument here to locate it within an introductory account of existing approaches to the construction of law's 'persons', which tend to reflect two broad positions. The first position is broadly 'naturalistic' in orientation ${ }^{25}$ and is represented by those theorists who see law's person as being archetypally a 'natural' person (the human being). The second position is broadly positivist, and adopts a conception of law's rights-bearing unit in the more functionalist or formal sense to be favoured (with certain caveats) for the purposes of this argument.

In naturalistic accounts, the legal person is always linked to a subtending natural person, and that natural person (the 'natural person' of law) is of human genetic origin. ${ }^{26}$ This 'natural' (human) subject is, moreover, conceptualised as being in possession of certain intrinsic qualities (such as 'dignity', 'autonomy' or 'rationality') - and is normally a person (paradigmatically, an adult) for whom legal rights function to augment or to provide public recognition of an underlying nature. Legal rights, on this view, operate as a kind of overlay upon an underlying set of characteristics taken to render such rights both apposite and intelligible. Human rights, for example, (read as both 'moral' and 'legal' rights) are deemed inherent to this natural subject and are understood to proceed directly, to borrow Kinley's language, from the 'natural condition of being a human'. ${ }^{27}$ This 'natural' subject forms the site at which the conflation between legal personhood and humanity is most explicit and intractable.

It is worth noting that the study of legal personhood as it applies to humans, once a key theoretical field of inquiry, is now 'no longer ... the subject of sustained theoretical analysis'..$^{28}$ Indeed, Berg has gone so far as to claim that 'legal personhood has largely been ignored outside of the corporate context', this despite the fact that many philosophers and concerned advocates have grappled explicitly with the meaning and implications of moral personhood in relation to extending legal rights to animals and other non-human beneficiaries. ${ }^{29}$ The general neglect of legal personhood, and in particular, of the human legal person, is a significant omission. First, the neglect of law's

\footnotetext{
${ }^{24}$ CD Stone, 'Response to Commentators' in 'Should Trees Have Standing? 40 Years On' (2012) 3 Special Issue Journal of Human Rights and the Environment 100 at 102.

${ }^{25}$ This position could even be described as 'natural essentialism' because it generally adopts a view of the 'natural person' (the human being) ascribing an essential characteristic as the foundation of personhood, most usually rationality and/or the possession of a soul. Naffine calls the position 'metaphysical realism' in her latest book, Law's Meaning of Life: Philosophy, Religion, Darwin and the Legal Person (Oxford: Hart, 2009), in which she designates 'naturalism' as a sub-set of metaphysical realist positions (including scientific notions of the human as a sophisticated animal (at 24)). The language of the 'naturalistic' will be deployed here, however, in order to emphasise the distinction between putatively 'natural' and putatively 'artificial' constructs of the person.

${ }^{26}$ Berg, above $\mathrm{n} 10$ at 373.

${ }^{27}$ D Kinley (ed), Human Rights in Australian Law: Principles, Practice and Potential (Sydney: Federation, 1988) at 5 - cited by N Naffine, 'The Nature of Legal Personality', in M Davies and N Naffine, Are Persons Property? Legal Debates about Property and Personality (Aldershot: Ashgate, 2001) at 55.

${ }^{28}$ Naffine, ibid, at 52. See also R Tur, 'The "Person" in Law' in A. Peacocke and G. Gillett (eds) Persons and Personality: A Contemporary Inquiry (Oxford: Blackwell, 1987) at 123.

${ }^{29}$ Berg, $\mathrm{n} 10$ above, at 370.
} 
construction of the natural person is significant because naturalistic suppositions are frequently in play in contemporary debate: When animal rights arguments draw links between rights and moral status, for example, and call upon a range of related justificatory concerns implied by the concept of being 'a person', they draw to an extent upon naturalistic suppositions - albeit modified. Secondly, despite the overwhelming dominance of naturalistic assumptions and the power of the convergence between the 'person' and the 'human being' in law, the 'natural person' of law does not adequately represent the human being qua human being. The perceived anthropocentrism/morphism of law (so often the target of animal-rights-based or eco-centric critiques of law) is far removed from being a concern with human beings in any rich and inclusive sense, as will be argued below, and the exclusions of approaches adopted in the name of 'nature' require particular critical attention in an age in which the very idea of the 'nature' itself stands so thoroughly problematised. ${ }^{30}$

The positivist account, by contrast, insists upon the 'emptiness' or 'formality' of the term legal 'person' as a referent without particular content or reference to sub-tending socio-material, moral, political or metaphysical characteristics. For positivist theorists, the concept of law's 'person' functions broadly as a formal reference to whatever law designates as bearing legal 'entity-status'. Derham, for example, explains that '[j] ust as the concept 'one' in arithmetic is essential to the logical system developed and yet is not one something (eg: apple or orange, etc.), so a legal system... must be provided with a basic unit before legal relationships can be devised which will serve the primary purpose of organizing the social facts. The legal person is the unit or entity adopted' ${ }^{31}$ While this unit is conceived of by some theorists as being a 'pure' unit of legal logic conceptually and functionally independent of any pre-existing social reality, this independence is in reality, leakier and less stable than some accounts would allow, as will be suggested below. Notwithstanding the need to qualify the degree to which this construct can escape or transcend materiality, however, the basic deployment of the 'legal entity' as a system-referent - a mere 'unit' of reference - can function as an important critical device providing certain advantages over the naturalistic approach, which remains inescapably entangled in the language and concept of the person.

\section{A terminological genealogy of the term 'person'}

The genealogy of the term 'person' reveals the origins and development of a (broadly naturalistic) confusion in the language and concept of the person - and paradoxically perhaps, underlines the fact that the term had an original conceptual clarity and an intrinsic sense of artificiality potentially theoretically consistent with an 'entity' conception of law's rights-bearing-unit.

The term 'person' began its genealogical journey with an original sense of the 'mask' - a literal translation from the Latin persona. ${ }^{32}$ Gradually, it attracted a substantive, naturalistic, humanity-

\footnotetext{
${ }^{30}$ See, for example, the writings of Haraway, especially D Haraway, Simeans, Cyborgs and Women: The Reinvention of Nature (New York: Routledge, 1991).

${ }^{31}$ Derham, 'Theories of Legal Personality', n 20 above at 5, emphasis added.

${ }^{32}$ See PW Duff, Personality in Roman Private Law (Cambridge, Cambridge University Press, 1938) at 3. Radin argues that '... there can be no doubt that 'person' is the Latin persona, the Greek prosopon, and that originally these words meant a 'theatrical mask', familiar to us as one of the devices of Greek and Roman theatre. From this, the meaning of 'role' was derived and by an almost inevitable metaphor, the dramatic role became that which any person plays in the drama of life': M Radin, 'The Endless Problem of Corporate Personality' (1932) 32 Columbia Law Review 643 - 667 at 645 . Keeton, for example, traces this semantic evolution all the way into
} 
centred content and eventually moved towards the eventual installation of the liberal individual as the fundamental unit and reference point of law. ${ }^{33}$ Accordingly, the term 'person' progressively evolved to gain a content increasingly implicating not just a human subjectivity, but a particular kind of human subjectivity, moving from an original sense of artifice towards, as Naffine puts it, 'a sovereign, reflective subject, a being with his own self-determining personality'. ${ }^{34}$

At one time, the more naturalistic implication of the term 'person' had existed 'side by side with persona in the original sense of "mask" or "role" or "function", indeed, both senses are to be found in literary and legal writings'. ${ }^{35}$ The conflation between 'personhood' and legal subjectivity arose at a later point in history when a degree of convergence in the semantics of 'personhood' became influential under the influence of Christian theology. Derham, for example, argues that the

more lasting confusion grew from the attempts of the early Christian theologians to grapple with the doctrine of the Trinity in the light of Greek (principally Aristotelian) metaphysics... By the sixth century Boethius was able to produce a definition of persona as 'the individuality of a rational being', and the primary use of the word to refer to the 'part played' was obscured. The ambiguity and confusion produced is with us yet. ${ }^{36}$

Arguably, however, the most complete conflation between personhood and rights-bearing status or legal subjectivity was achieved with the historical emergence of liberal individualism. It was at this time that the word 'person' was chosen as the 'terminus technicus to designate the subject of rights'. ${ }^{37}$ With the shift from feudal 'status'-driven relations to modern social and legal relations predicated on 'contract', the liberal individual effectively became the fundamental unit of law. ${ }^{38}$ Nekam argues that it is precisely with the emergence of individualism that an anthropomorphic assumption entered the discourse of the legal entity and the term 'person' gained its problematic semantic complexity: The 'person' had evolved into the designation of the combination of a rightsbearing legal subject and a human individual (and the physical, psychological and metaphysical qualities that human communities think they are justified in assigning to it). ${ }^{39}$ The legal 'person' had become the archetypal manifestation, arguably, of naturalist philosophical commitments.

\section{Three identifiable conceptions of law's entity}

Naffine - an exception to the general neglect of the theory of law's person as it relates to the human being - has conducted a careful analysis of existing law and jurisprudence to produce a schematic of

legal personhood, noting the layer by layer accretion of substantive content attaching to the term 'person', which was used first to 'denote ... the part played by a man in life, and still later, the man who plays it. ... Last of all, the term comes to denote a being capable of sustaining legal rights and duties': GW Keeton, The Elementary Principles of Jurisprudence (London: Sir Isaac Pitman and Sons, 1930) at 117, cited by Naffine, n 27 above at 57.

${ }^{33}$ Keeton, n 32 above at 117, cited by Naffine, n 27 above at 57.

${ }^{34}$ Naffine, ibid.

${ }^{35}$ Radin, above, n 32, at 646, who suggests (at fn 8) that the 'instances cited under persona in the Forcellini Lexicon make the uses of the word clear enough'.

${ }^{36}$ Derham, 'Theories of Legal Personality', above, n 20, at 13.

${ }^{37}$ Nekam, above, n 22, at 48.

${ }^{38}$ As documented, most famously, by H Maine, Ancient Law: Its Connection with the Early History of Society and its Relation to Modern Ideas (London: John Murray, 1930).

${ }^{39}$ Nekam, above n 22, at 49. 
three identifiable conceptions of 'law's person' (P1, P2, P3). Hers is important work, especially in the light of the fact that in the main, courts deploy the language of legal or juridical personhood atheoretically and without clear agreement on its meaning. ${ }^{40}$ Naffine's analytical cartography can also be seen as a contribution to the foundations of a more general theory of legal subjectivity - now vitally important in the light of the fact that the definitional problem of the law's person is set to become ever more complex in the light of technological, social and intellectual developments, ${ }^{41}$ as noted in the introduction to this article.

The exploration to be offered here deploys Naffine's broad template as a point of departure for a fuller development of an account of the forms of legal subjectivity and their implications. The account to be offered here will refer to all three conceptions (including law's 'natural' persons) as being constructs or entities. A distinction will, however, be drawn between the positivist 'entityentity' (E-E1 - in which the entity-status of law's subject as constructus is made explicit) and the two naturalistic 'person-entities' (P-E2/P-E3 - in which the constructed nature of the entity or conception involved is submerged or muted beneath naturalistic assumptions and rhetorical practices).

Although in some ways it would be simpler to render these E-E and P-E1 and P-E2, the numerical designation chosen is an attempt to keep clear the relationship between Naffine's original analysis and this deployment of it. The term 'person-entity' is a deliberate if somewhat cumbersome reference to the fact that law has an operative conception of a 'human person' (P-E2) and of a closely related human 'rational actor' (P-E3) - and that both of these, despite their naturalistic gloss, are constructs. Both, in their particular but related ways also fail, along highly patterned and particularistic lines (as will be argued below) to do full justice to the embodied complexity of human life in its rich and messy psychosomatic and socio-somatic matrices - and both, fairly systematically and with differing degrees of subtlety, tend to exclude certain categories of human being from being paradigm instances of law's autonomous, individual actor.

Naffine's analysis of existing theoretical accounts and Anglo-American case law identifies first a conception of law's person (P1) corresponding more or less directly with Nekam's rights-bearingfunctional-legal-entity (E-E1). This is the 'legal entity' as 'bare analytical construct: 'nothing more than the formal capacity to bear a legal right and so to participate in legal relations' ${ }^{42}$ By contrast, ' $\mathrm{P} 2$ ' is the definition applied to the 'animate being' and coheres around the legal terminology of 'any reasonable creature in being' (a quintessentially human designation), resting upon 'biological and metaphysical definitions of humanity' (P-E2). ${ }^{43}$ 'P3' is the 'responsible subject,' or the 'rational and therefore responsible human legal agent or subject - the classic contractor' ${ }^{44}$ This construct represents the archetypal political and legal actor of liberal theory and is here designated as the person-entity P-E3 which takes the form, above all, of the 'rational human actor'. Naffine's analysis reveals that E-E1, as we would expect from our brief foray into Nekam's theoretical argument, need not be human at all (and therefore, she suggests, includes the corporation). P-E2 is the conception

\footnotetext{
${ }^{40}$ Indeed, the metaphor of the legal 'person' is deeply obscured by a set of rhetorical practices in the almost complete absence of any coherent body of doctrine or theory regarding its nature: See Note, 'What We Talk About When We Talk About Persons: The Language of a Legal Fiction' (2001) 114 Harvard Law Review 1745 at 1746.

${ }^{41}$ Ibid, and Naffine, above, n 13, at 346.

${ }^{42}$ Naffine, above, $\mathrm{n} 13$, at 350 .

${ }^{43}$ Ibid, 357.

${ }^{44}$ Ibid, 362.
} 
most intimately related to the biological identification of a natural living human being, while P-E3 further constricts the legal construct of the underlying human being by elevating a characteristic (rationality) (itself read in a particular way) taken to qualify someone for the status of 'person'. This has the result that, as we move from E-E1 to P-E2 to P-E3 'there is a progressive exclusion of beings from the privileged status of person and thus the legal circle or legal community steadily diminishes. ${ }^{45}$ We can also add that there is a subtle and complex movement from explicit artificiality towards a constructed naturalism.

E-E1, as the 'formal capacity to bear a legal right and so to participate in legal relations' is essentially 'empty'. Anything can be a legal entity because 'legal [entities] are stipulated as such or defined into existence' ${ }^{46}$ This means that E-E1 is highly plastic and, in theoretical terms at least, potentially limitless in its reach. E-E1-type accounts of legal subjectivity also make explicit the fact that the 'human being', as such, is in the context of law nothing more than the sets of legal relations addressing or applied to a subtending human referent. For Kelsen, for example, the legal entity is nothing more than a point of convergence for norms - an empty placeholder in a nexus of legal relations, not a tangible 'something' or 'anything' in an everyday sense. Kelsen's legal person is 'the unity of a complex of legal obligations and rights. Since these obligations and rights are constituted by legal norms (more correctly: are these legal norms), the problem of "person" is in the last analysis the problem of the unity of a complex of norms' ${ }^{47}$ The implication of this in relation to the 'human being' is that the 'so-called physical person ... is not a human being, but the personified unity of the legal norms that obligate or authorise one and the same human being' ${ }^{48}$ The gap between the legal entity and the human being - or indeed any subtending anything - is made explicit on such an account.

The E-E1 conception of the legal entity, moreover, is infinitely malleable. On an E-E1 account, law can explicitly multiply both the entities it creates and variations in the relations between them, lending E-E1 considerable plasticity. The E-E1 facility for multiple extensions of legal status, taken seriously, implies that E-E1 could stand for a convergence of norms directed towards a human being, an animal, a corporation, a system, a sub-system - even at a micro-scalar level of focus - indeed, for almost anything - theoretically at least. Naffine rightly points out that, although E-E1 might appear to be the 'least interesting, most colourless and abstractly formal type of legal person ${ }^{\prime 49}$ the very blankness of the entity is precisely what grounds an account of legal subjectivity responsive to a wide range of putative candidates. Furthermore, E-E1's agnosticism and plasticity - its 'artificiality' can be emphasised to advertise, almost as an immanent characteristic of its linguistic and conceptual constitution, its own contingent, malleable, constructed nature. This malleability gives EE1 a certain potential responsiveness to complexity, moreover. It is not locked into any particular pre-existing form - it is protean and can evolve in response to law's changing needs. E-E1 'fits', as it

\footnotetext{
${ }^{45}$ Ibid, 365.

${ }^{46}$ Naffine, 'Who are Law's Persons?' above n 13 at 351. See also fn 20 where she attributes the phrase 'defined into existence' to Natalie Stoljar.

${ }^{47}$ H. Kelsen, Pure Theory of Law (Berkeley: University of California Press, 1967) 173-4.

${ }^{48}$ Ibid.

${ }^{49}$ Naffine, above $\mathrm{n} 13$ at 350 .
} 
were, the need for plasticity in an age of plasticity. It offers a useful construct through which to mediate law's own necessary plastic organisation as a system - fluid, open, potentially adaptive to a wide range of future imperatives.

The E-E1 conception has a further important advantage, however. It has the advantage of being amenable to critical deployments drawing attention to the gap between E-E1 and the living, malleable affectability of socio-materiality implicated in law's coordinative task. In an age of mounting pressure concerning the endangerment of animals, eco-systems and so forth, E-E1 possesses a theoretically flexible, virtually unlimited potential for multiplying law's entities while usefully, and simultaneously, pointing to law's strategies and limits. (The advantages of this will become particularly clear when we examine the negative implications of P-E2 and P-E3, below.)

E-E1's relationship with socio-materiality is somewhat complex. Quite apart from its prospective lack of independence from emergent justificatory arguments for the production of new legal entities arising from 'beyond law's artificiality' in arguments about vulnerability, moral personhood and the like, E-E1 is attended by interesting theoretical questions concerning the degree to which it can avoid materialisation once it is put to work in the legal system..$^{50}$ Materialisation seems inescapable given law's nature as practical reasoning designed to coordinate relations and yield outcomes in a socio-materially 'thick' world. Legal norms and constructs, after all, have an inherently 'non-law' facing nature. ${ }^{51}$ They possess an intrinsic orientation towards the socio-material and all jural constructs can be seen to implicate a 'flesh-and-blood' dimension. Even the most explicitly fictive elements of law, the most notionally spectral of juristic creations (those emerging in the 'contemplation of' the mind of law alone ${ }^{52}$ ) have inescapably generative effects in socio-material terms: they 'act' on the world, sooner or later, as a direct result of (and possibly even as a condition for) their deployment as categories of legal thought or conceptualisation. Nekam goes further, arguing that the legal entity is also 'always something in whose experimental (by which he seems to mean empirical) existence the community believes', although he insists that the 'legal entity' is only the legal image of this empirical something because the legal entity will only possess those characteristics with which the law imbues it, and, accordingly, that 'all the other eventual qualities of the beneficiary will be totally immaterial from [the law's] point of view'. ${ }^{53}$

However, Nekam's view arguably underplays the implications of the question of the shape of the 'immateriality' excluded by law, overstating the degree to which the characteristics grounded in the empirical/socio-material can ever be truly immaterial to the construction of law's entity. Naffine has argued that in their insistence on the idea of the legal entity as a formal concept, it is possible that positivist accounts have 'demonstrated a wilful blindness' to the empirical character of law's

\footnotetext{
${ }^{50}$ Naffine, above, n 13 at 355.

${ }^{51}$ N. MacCormick and O. Weinberger, An Institutional Theory of Law: New Approaches to Legal Positivism ((Dordrecht, Boston, Lancaster and Tokyo: D. Reidel Publishing Company, 1992) at 15.

${ }^{52}$ A good example of this is provided by the English legal concept of 'incorporeal hereditaments': 'certain intangible rights over or in respect of land and, not being "the object of sensation", can neither be seen nor handled but are "creatures of the mind, and exist only in contemplation" (BI Comm, Vol II, p 17) ... The statutory definitions of "land" effectively bring about a remarkable reification of intangible entitlement $-\mathrm{a}$ frequent feature of the common law mindset': K Gray and SF Gray, Land Law (London, Butterworths, 2003) at 4.

${ }^{53}$ Nekam, above, n 22 at 40 .
} 
personification and have thereby inhibited the possibility of fertile theoretical dialogue on the subject, removing, moreover, the 'analysis of the legal person from its socio-political context ${ }^{54}$ and occluding examination of the socio-political function of legal personhood. ${ }^{55}$ She suggests that positivist theorists have generally 'tended to cease their theorising at the very point at which it becomes most interesting and so have simply not engaged with the question of the form of law's personification' ${ }^{56}$

From a critical point of view, the form of E-E1's personification is a question that will require ongoing and reflexive engagement if E-E1 is to fulfil the inclusory promise of its artificiality, malleability and relative agnosticism. It will be important to examine E-E1's forms of materialisation and to draw attention to precisely what or who might be 'othered' by law's commitments as mediated through the construct. It is of particular note, for example, that existing critical accounts suggest a highly patterned selectivity in relation to the characteristics of the empirical 'something' that law is willing to deploy or acknowledge as a legal subject - a patterned selectivity moreover reflecting identifiable characteristics and suppositions concerning the particularities of 'natural' human being of law, revealed when E-E1 materialises - as it historically has tended to- as P-E3. ${ }^{57}$ Unless this tendency is transcended, E-E1 cannot begin to achieve the radically inclusory potential of its 'emptiness'. But even in some future world where (perhaps implausibly) the tendency to manifest as P-E3 is successfully overcome, the question of the patterns of E-E1's materialisation can never be put aside. The question of materialisation will always require epistemic and critical vigilance - a persistent, justice-sensitive engagement with the question of precisely what or who is 'othered' by the materialisation of even this most promisingly agnostic of conceptions of the legal entity. ${ }^{58}$

E-E1, I suggest, offers particularly rich possibilities from the critical point of view. Its insistence on the fact that law's entity is but a constructus made up of intersecting normative relations within law's systemic thought-stream is a potentially most powerful way of rendering naked, as it were, the systemic gap between law and complex, dynamic, relationally-productive materialities. The very artificiality of the constructus as explicit constructus opens up an intelligible space for critique, inviting a new level of vigilance concerning the forms and implications of the materialisation of E-E1. E-E1's artificiality highlights, I suggest, a useful critical gap obscured or missing in naturalistic accounts of law's subject, tending - as they do - to reify a 'natural' construct in a way masks its artificiality, selectivity and partiality.

\footnotetext{
${ }^{54}$ Naffine, above, n 27, at 69.

${ }^{55}$ Ibid.

${ }^{56}$ Ibid, at 68.

${ }^{57}$ Naffine, above n 13, at 356.

${ }^{58}$ At the conceptual level alone, 'othering' plays an indispensable role in the identity of any concept: M Davies, 'The Identity of Law' (2005) 5 Macquarie Law Journal 5-30. If concepts exist in a system of differences which are culturally and linguistically constructed through the exclusion of 'contiguous and oppositional concepts' (F de Saussure, Course in General Linguistics (trans 1959) at 117, cited by Davies, at 7), E-E1will minimally be haunted by the (negative) conceptual necessity of an excluded other which intrudes (precisely because of its very definitional indispensability) into its identity and is thus implicit in its definition. Moreover, if, as Laclau argues, a 'trace of the excluded term is left, meaning that identity is not total or complete in itself, and there is an ongoing need to deny the other, to keep it outside [then] [e]xclusion is ... an exercise of power or border control which is an ongoing process, not a single act' (E Laclau, Emancipation(s) (London: Verso, 1996), cited by Davies, at 9). E-E1 will, even at the conceptual level, always require epistemic vigilance - and the need for this only intensified by the realities of socio-political life and the dominance of P-E3 in law, as will be argued here.
} 
Naffine, as already noted, also identifies two templates of the 'natural person' in law: P2 (P-E2) and P3 ( $P$-E3). Both these constructs presuppose a 'natural human being' as the substrate of the 'person' in law and rest on operative suppositions concerning 'an intrinsic' human nature. P-E2 theories focus most directly, according to Naffine, upon the simple 'natural condition of being human' in law. ${ }^{59}$ This 'human' is legally defined - and rests upon certain biological and metaphysical assumptions concerning the meaning of being 'human', or counting as 'human'. The position presupposes a living human being and a human being becomes a legal being in the P-E2 sense 'at birth, which is also legally defined, and stops being a legal person at whole brain death, legally defined'..$^{60}$ As Naffine points out, in such accounts, legal rights are seen as a mere augmentation of what are taken to be innate moral attributions of 'natural' persons.

This conception of law's entity is arguably the most complex in its relationship with legal anthropocentrism and has been described as being 'almost axiomatic' for human rights lawyers. ${ }^{61}$ Naffine notes, for example, that Article 1 of the Universal Declaration of Human Rights is the paradigmatic statement of P-E2. A closer examination of human rights law, however, even at the putatively 'human-family'-centred international level, reveals certain patterned (some would say, predictable) closures at play. ${ }^{62}$ P-E2 is, in a sense, meant to stand for all of us, yet the commitments underlying the construct have been convincingly linked, by a range of critical scholars, to the replication of hierarchies and marginalised subjectivities even within international human rights law (that most 'human being' centred of all legal regimes). ${ }^{63}$ P-E2 relies on biological definitions of the human - and melds biology (itself extensively constructed and bearing an oppressive social history ${ }^{64}$ ) with overtly metaphysical assumptions ${ }^{65}$ identified by critical accounts as bearing problematic implications linked to exclusory assumptions underlying the disembodied conception of the autonomous person (both philosophical and legal). ${ }^{66}$ These self-same assumptions and

\footnotetext{
${ }^{59}$ Naffine, above n 13, at 358, quoting D. Kinley, (ed) Human Rights in Australian Law, above n *, at 5.

${ }^{60}$ Ibid, 357.

61 Ibid, 358.

${ }^{62}$ A Grear, 'Framing the Project: The Dysfunctional Family of the Universal Declaration of Human Rights' in C Gearty and C Douzinas (eds) The Cambridge Handbook on Human Rights (Cambridge, CUP, 2012) (forthcoming).

${ }^{63}$ See, for example, F Beveridge and S Mullally, 'International Human Rights and Body Politics' in J Bridgeman and S Millns (eds) Law and Body Politics: Regulating the Female Body (Aldershot: Dartmouth, 1995); C Bunch, 'Women's Rights as Human Rights: Toward a Re-Vision of Human Rights' (1990) 12 Human Rights Quarterly 486; H Charlesworth, 'Midlife Crisis of the Universal Declaration of Human Rights' (1998) 55 Washington Lee Law Review 781-796; D Otto, 'Violence Against Women: Something Other Than a Human Rights Violation?' (1993) 1 Australian Feminist Law Journal 159; D Otto, 'Disconcerting “Masculinities": Reinventing the Gendered Subject(s) of International Human Rights Law in D Buss and A Manji (eds) International Law: Modern Feminist Approaches (Oxford, Hart Publishing, 2005) 105-129;D Otto, 'Lost in Translation: Rescripting the Sexed Subjects of International Human Rights Law' in A Orford (ed), International Law and its Others (Cambridge: Cambridge University Press, 2006); R Kapur'Human Rights in the $21^{\text {st }}$ Century: Take a Walk on the Dark Side' (2006) 28 Sydney Law Review 664.

${ }^{64}$ A Fausto-Sterling, Sexing the Body: Gender Politics and the Construction of Sexuality (New York: Basic Books, 2000).

${ }^{65}$ Concerning, for example, autonomy, dignity, freedom and the like - which have all been extensively interrogated and criticised for privileging a particular notion of the human.

${ }^{66}$ See J Nedelsky, Law's Relations A Relational Theory of Self, Autonomy, and Law (Oxford: OUP, 2011); M Fineman, The Autonomy Myth: A Theory of Dependency (New York: The New Press, 2003).
} 
exclusions are linked by such accounts to the very epistemologies and practices of ecological destructiveness ${ }^{67}$ now animating concerns for the extension of legal subjectivity to animals and the environment. In fact, a range of critical accounts of P-E2 suggestively imply that installed within its cognitive architecture is a highly particular, gendered, raced construct. ${ }^{68}$ This critique has produced, for example, various feminist strategies (reconstructing the universal as a double subjectivity, ${ }^{69}$ particularising the masculine ${ }^{70}$ and inverting existing gender scripts ${ }^{71}$ ), none of which, to date, have successfully solved the fundamental exclusory quandary presented by P-E2. On closer examination, moreover, especially in its instantiation as the abstract universal, the closures of P-E2 are intimately related to the contours of the P-E3 conception of the 'natural' legal subject. Thus, while P-E2 is more potentially inclusive of human beings than the P-E3 conception, its socio-historical implications have not been inclusive despite its universalistic aspirations, rhetoric and (some would say) pretensions. In short, P-E2 (just as E-E1) has, in its materialisation, tended to reveal the overwhelming dominance of the P-E3 construct of law's person/entity and, as a result, international human rights law fails, as Otto notes, to fulfil its most fundamental premise: its commitment to the 'whole human family' and to the principle of non-discrimination, ${ }^{72}$ such that, as Douzinas has argued, '[o]nce the slightest empirical or historical material is introduced into abstract human nature, once we move from the declarations onto the concrete embodied person, with gender, race, class and age, human nature with its equality and dignity retreats rapidly'. ${ }^{73}$

Since P-E2 is, in a very real sense, a more subtle manifestation of $P-E 3$, and since E-E1 has, thus far, historically tended to materialise as P-E3, it is on P-E3 that we shall focus most of our critical attention for present purposes.

\section{P-E3: the autonomous, rational actor}

\footnotetext{
${ }^{67}$ See L Code, Ecological Thinking: The Politics of Epistemic Location (Oxford: OUP, 2006), who proposes an epistemic revolution comparable to the Kantian shift which installed 'man' as the centre of the universe. She points out that the recognition of the parochialism of Kant's conception of 'man', and which lay at the heart of what she names as 'Kant's Copernican revolution' in the sphere of the philosophical-conceptual, is recognised by a range of theoretical stances: feminist, socialist, post-colonialist and by critical race theory (at 3). Code's thesis links the epistemological closures of the West fairly unambiguously to environmental devastation. See also K Bosselmann, 'Losing the Forest for the Trees: Environmental Reductionism in the Law' (2010) 2 Sustainability 2424.

${ }^{68}$ Otto, 'Disconcerting "Masculinities"', above n 63. See also Kapur, above n 63.

${ }^{69}$ L Irigaray, Thinking the Difference: For a Peaceful Revolution (trans. K. Montin) (New York: Routledge, 1994).

${ }^{70}$ Otto, 'Lost in Translation', above $\mathrm{n} 63$ at 353-4. What Otto has in mind is the reimagining of men as 'injured by the hierarchies of gender' (at 353). She provides conscription, given its coercive nature, as a possible candidate for this reimagining, but rightly suggests that it is not easy to equate the idea of gender privilege as an injury to men with the injury done to women through their lack of gender privilege, not least, because 'women do not benefit from men's gender injuries' (at 353). A real risk (and a double bind) in reimagining men as injured by the construction of their gender privilege (at least without any broader transformation or disruption of the encoded hierarchies of the gender binary) is the risk of further marginalising women (at 354).

${ }^{71}$ Otto, 'Lost in Translation', above $\mathrm{n} 63$, at 354. The suggestion is that the equality approach could be made to work both ways, challenging gender hierarchy in the process, but the best evidence suggests that privilege remains 'attached to male bodies'. However, Otto maintains that this approach at least has the merit of suggesting the fluidity of sex and gender roles, which tends to reveal the social nature of their origins.

${ }^{72}$ Otto, 'Disconcerting "Masculinities"', above n 63, at 105-6. Emphasis added.

${ }^{73}$ Douzinas, above $\mathrm{n} 23$ at 96.
} 
P-E3 is a naturalistic construct which further narrows the remit of 'human' or 'natural' legal 'personhood' by explicitly elevating certain characteristics deemed to be determinative of rightsbearing capacity and status -drawing out, in a sense, the suppositions of P-E2 more overtly. P-E3 places a focal emphasis upon a particular conception of human rationality (narrowly conceived ${ }^{74}$ ) and the "mentally and legally competent human adult" ${ }^{75}$ supplies its operative trope. This adult is presumptively male: the archetypal rational, choosing, will-exercising 'discrete possessor of rights', ${ }^{76}$ distinctly bounded and separative. ${ }^{77}$ This trope has been identified by feminists as being the fully autonomous man upon whom legal and political subjectivity is currently overwhelmingly founded. ${ }^{78}$ Naffine argues that P-E3 is 'a conspicuous departure from ordinary-language meanings of the term [legal person]. In this sense it is more akin to P1 [/E-E1] than P2 [/P-E2]: it is a technical legal term whose meaning may be regarded as interior to law'. $^{79}$

Despite its putative legal 'interiority', however, P-E3 is, in a sense, but the juridical register of a set of broader commitments, also reflected in P-E2, and converging in the complex of the political, economic and legal actor. P-E3 has, in this sense, a pervasive presence as a powerfully naturalised ideological construction of the 'human person' with extensive reach across the entire spectrum of social domains. It represents the quintessence of the 'rational and therefore responsible human legal agent or subject: the classic contractor, the individual who is held personally accountable for his civil and criminal actions ... ${ }^{80}$ whose rational choice founds the liberal political order and operatively navigates and structures market-relations. P-E3 has been almost univocally unmasked, from a range of critical perspectives, as structurally privileging the white, male, property-owner and central-case citizen, the archetypal 'natural' man whose civic life emerges from contract and whose bounded self is analytically co-dependent with liberalism's private property construct. ${ }^{81}$ Naffine suggests that P-E3 is also 'impossibly self-possessed and self-reliant, will-driven, clinically rational and individualistic. Certainly he is never pregnant, for this would threaten his physical integrity. Also he is not to be thought of as a wife' $.^{82} \mathrm{P}-\mathrm{E} 3$, then, appears to be, in many respects, the submerged primary beneficiary of law in Western cultures - a point amply supported by the important fact that, as has already been noted, both E-E1 and P-E2 tend to materialise as P-E3. Another way of looking

\footnotetext{
${ }^{74}$ Code, above n 67 , at 3 .

75 Naffine, above n 13, at 362. See also J Dawson, 'The Changing Legal Status of Mentally Disabled People' (1994) 2 Journal of Law and Medicine 41.

${ }^{76}$ Ibid.

77 J Nedelsky 'Law, Boundaries and the Bounded Self' (1990) 30 Representations 162.

${ }^{78}$ For an argument concerning the absence of women as legal persons as women see N Naffine, 'Women and the Cast of Legal Persons' in J Jones, A Grear, RA Fenton and KL Stevenson, Gender, Sexualities and Law (Abingdon: Routledge, 2011) 15-25. For a developing critique of the autonomous subject and its implications, see MA Fineman, The Autonomy Myth The Autonomy Myth: A Theory of Dependency (New York: The New Press, 2003); MA Fineman, 'The Vulnerable Subject: Anchoring Equality in the Human Condition' (2008) 20 Yale Journal of Law and Feminism 1.

${ }^{79}$ Naffine, above, n 13, at 365. Interestingly, it has been drawn to my attention by Alice Belcher that an analogous 'rational economic man' can be regarded as interior to economics, functioning in a similar way to P3 in law, as an ideal actor, irrespective of how real people make their economic decisions.

${ }^{80}$ Naffine, above, $\mathrm{n} 13$, at 365.

${ }^{81}$ For fuller discussion of the traditional liberal property construct in relation to human rights, see A. Grear, 'A Tale of the Land, the Insider, the Outsider and Human Rights,' (2003) 23 Legal Studies 33-65. For an extended discussion of the links between the concept of the legal person and property in liberal theory, see Davies and Naffine, above, n 27.

${ }^{82}$ Naffine, above, n 13, at 365.
} 
at this materialisation pattern would be to conceptualise P-E3 as reflecting values and commitments sub-tending the entire gendered liberal legal schema in its current dominant formulation which emerge in differing and sometimes complicated ways in all three constructs of law's entity.

Accordingly, all three constructs can be read as being ideologically tilted, though to differing degrees - suggesting that legal subjectivity as a mechanism 'fairly systematically ... [supports]... a quite particular interpretation of the person. ${ }^{83}$ The dominance of P-E3, therefore, suggests that it has a particular importance for understanding the present limitations of contemporary legal subjectivity.

\section{Linking P-E3, the exclusions of legal naturalism and the dominance of the corporate form}

There are observable trajectories of privilege and oppression linked to the epistemological underpinnings, ontological assumptions and ethical failures associated with the P-E3 construction of legal subjectivity which have been linked to contemporary forms of injustice and exclusion and to the dangers facing human communities, natural ecosystems and the world population as a whole. ${ }^{84}$ In this light, the dominance of P-E3 is an important subject for proponents of extending legal subjectivity to animals and the environment to consider. It seems essential that such proponents should fully appreciate critiques of the contemporary constitution of legal subjectivity and address its gravitational tendencies towards patterned forms of privilege and oppression. Proponents of animal and environmental rights, for example, frequently attack the 'anthropocentrism' of law, arguing that law (perhaps especially human rights law) amounts to a form of 'philosophical speciesism' ${ }^{85}$ However, the dominance of P-E3 (and the intimately related exclusions of P-E2) suggest that legal anthropocentrism does not straightforwardly elevate 'human interests' at all so much as elevate a particular construct of the human person which systematically advantages those best able to deploy some relevant degree of correspondence to it. It is not going too far to suggest that both P-E2 and P-E3 fail to embrace an 'anthropos' in any sense that guarantees the inclusion of the living human being qua human being. Indeed, this radical failure of inclusion is one of the most telling criticisms levelled at the Universal Declaration of Human Rights, that putatively most 'humanity-centred' declaration of humanitarian concern. ${ }^{86} \mathrm{It}$ is arguably vital for those concerned to extend legal subjectivity to animals and the environment, or indeed to other beings, entities or systems, to attend to the fact that P-E3 retains a stubborn centrality in law - this notwithstanding

\footnotetext{
${ }^{83}$ Naffine, 'The Nature of Legal Personality', above $\mathrm{n} 27$ at 56. Emphasis added.

${ }^{84}$ This is the clear implication of, for example, Code's work (see above $\mathrm{n}$ 67), and that of others, such as Shiva, whose work exposes the dense inter-weavings of the patterned epistemic, ontological and ethical reductionisms involved in human and ecological devastation. See, for examples of her insightful work, V Shiva, Staying Alive: Women, Ecology and Development (London: Zed Books, 1989); V Shiva and I Moser, Biopolitics: A Feminist and Ecological Reader on Biotechnology (London: Zed Books, 1995); V Shiva, Stolen Harvest: The Hijacking of the World Food Supply (Cambridge MA: South End Press, 2002).

${ }^{85}$ To borrow the term deployed by Gearty: C Gearty, 'Do Human Rights Help or Hinder Environmental Protection?' (2010) 1/1 Journal of Human Rights and the Environment 7-22 at 8; C Gearty, 'Is Human Rights Speciesist?' in A Linzey (ed) The Link Between Animal Abuse and Human Violence (Brighton: Sussex Academic Press, 2009) Chapter 15.

${ }^{86}$ Hannah Arendt famously argues in The Origins of Totalitarianism (New York: Harcourt, 1971) that human rights 'based on the assumed existence of a human being as such broke down at the very moment when those who professed to believe in [them] were for the first time confronted with people who had lost all other qualities and specific relationships - except that they were still human' (at 299). The 'refugee' represents the very figure which should most completely embody an international human rights subjectivity founded on the human being qua human being as such, yet Article 14 UDHR fails to guarantee refugees the right to enter another country producing a highly revealing betrayal of the promise of universalism.
} 
the broader cultural impact of post-structural, post-humanist and bio-technological insights into the instability of humanity as a category. It is especially important to recall that P-E3 (and to a more muted extent P-E2) is a construct which has historically deployed an incipient categorisation of human beings into hierarchies of rationality and dignity - a hierarchy which has effectively excluded an entire range of 'non-dominant' humans ${ }^{87}$ - operatively uniting them, in fact, with non-human animals ${ }^{88}$ and other living systems from the full protective concern of the law. ${ }^{89}$

P-E3 continues to operate as a decisively important and problematic 'insider-outsider' mechanism, albeit often in more complex ways than it did in less notionally equality-sensitive social eras. Unless the dominance of P-E3 is addressed, it is likely that strategies for the extension of legal subjectivity run the genuine risk of a dangerous naivety. Critical legal accounts sensitive to the socially contingent and paradoxical nature of both rights and legal subjectivity assume a far less benign relationship between law and protection than do most arguments for the extension of rights or legal subjectivity to putative new claimants. The relative lack of engagement, noted by Berg, with questions of legal personhood beyond the issue of corporate personhood, ${ }^{90}$ (and compared to arguments addressing the moral personhood of animals, the environment, intelligent machines and so forth) presents a theoretical omission in urgent need of exploration.

P-E3 stands at the heart of many critical accounts of legal subjectivity. So too does a dense intimacy between liberal law and capitalism. Indeed, a range of accounts suggest liberal legality (characterised by the primacy of contract and property rules within a formally equality-based juridical framework) as being 'the mechanism by which capital dominates civil society'. ${ }^{91}$ Let us attend more closely to this suggestion and its implications in relation to the 'identity' of P-E3, its 'others', and its implications in the contemporary contexts now driving the debate about extending legal subjectivity.

The broad argument that law is the mechanism by which capital dominates civil society has been particularly linked to critical readings of the nineteenth century period in which capitalism became the dominant mode of production. ${ }^{92}$ It has been argued, for example, that modern science and

\footnotetext{
${ }^{87}$ Applying such analysis to human rights, for example, Baxi argues that '[w] hat counted as reason and will varied in the course of the long development of the European liberal traditions; however, the modern paradigm of human rights, in its major phases of development excluded 'slaves', 'heathens', 'barbarians', colonized peoples, indigenous populations, women, children, the impoverished, and the 'insane', at various times and in various ways, from those considered worth of being bearers of human rights. The discursive devices of Enlightenment rationality constituted the grammars of violent social exclusion'. U Baxi, The End of Human Rights (Oxford: OUP, 2006) at 44, emphasis original.

${ }^{88}$ M Dekha, 'Intersectionality and Post-human Visions of Equality' (2008) 23 Wisconsin Journal of Law, Gender and Society 249. For more, see also (as referenced by Dekha) S Salih, 'Filling Up the Space Between Mankind and Ape: Racism, Speciesisim and and the Androphilic Ape' (2007) 38 Ariel 95; R Corbey, The Metaphysics of Apes: Negotiating the Animal/Human Boundary (Cambridge: CUP, 2005).

${ }^{89}$ This insight, central to eco-feminist critiques, is also supported by sociological accounts of the oppressions enacted by industrial and corporate capitalism - see D Nibert, Animal Rights, Human Rights: Entanglements of Oppression and Liberation (Oxford: Rowman and Littlefield, 2002). Dekha above n 88.

${ }^{90}$ Berg, above n 10.

${ }^{91}$ M. Neocleous, 'Staging Power: Marx, Hobbes and the Personification of Capital' (2003) 14 Law and Critique $147-165$, abstract.

${ }^{92}$ B. De Sousa Santos, Towards a New Legal Common Sense: Science and Politics in Paradigmatic Transition (London: Routledge, 1995) at 39.
} 
modern law were produced as related facets of a rationalistic discourse ${ }^{93}$ which tended to cloak the exclusionary implications of the elevation of P-E3 as the proto-beneficiary of a capitalist legal and political order. It has been suggested that 'the violence at the heart of law and of public and private power, which had helped re-organise the world according to the new political and economic orthodoxies, was written out of the texts of the law', ${ }^{94}$ and that law was re-constituted as a supremely rational state product in a socio-temporal context in which the disciplinary power of the state was united with science to produce new forms of social control, as Foucault so brilliantly argued. ${ }^{95}$ Law was re-imagined, idealised as a rational, technical formalism aimed at logical coherence, seamless coverage and certainty which, for Weber at least, amounted to a form of 'domination' 'legitimated by the rational system of state-enacted universal and abstract laws, presiding over a bureaucratic and professional administration, and applied throughout society through a form of justice based on logical formal rationality'. ${ }^{96}$ Santos argues that 'the rise of positivism in the epistemology of modern science and the rise of legal positivism in law and jurisprudence belong together as ideological constructs aimed at reducing social progress to capitalistic development'. ${ }^{97}$

Capitalistic development in the decisive nineteenth century time frame has particular implications relating to a marked intimacy between P-E3 and the corporate form, the dominance of which has had, ${ }^{98}$ and continues to have a decisive impact upon the 'others' of P-E3 legal subjectivity. ${ }^{99}$ It is important to note as a preliminary matter that P-E3 ideology is thoroughly implicated in the nineteenth century consolidation of the power of the emergent capitalist class. Norrie's account of the reconstruction of English criminal law in the nineteenth century, ${ }^{100}$ for example, reveals their relentless priority in the modernisation project of the law reformers. It also reveals law's attempted excision of social context in the search for a pure application of legal rationalism, and the analytically co-dependent hypostatisation of P-E3 in the context of criminal law - a convergence of elements ultimately revealing the patterned, socially-constructed limits of legal rationality itself. ${ }^{101}$ It is Norrie's explicit contention that the criminal law was developed by the nineteenth century criminal law reformers precisely to safeguard emergent propertied interests. ${ }^{102} \mathrm{~A}$ central consequence of the

\footnotetext{
${ }^{93}$ Santos, ibid, at 40.

${ }^{94}$ Douzinas, above n 23, at 67.

${ }^{95}$ M Foucault, Discipline and Punish: The Birth of the Prison (A. Sheridan, trans) (New York: Vintage, 1995);

M Foucault, The History of Sexuality: An Introduction (R. Hurley, trans) (London: Penguin, 1981).

${ }^{96}$ Santos, above, n 92, at 41.

${ }^{97}$ Ibid, at 40.

${ }^{98}$ See R Grantham and C Rickett, 'The Bookmakers Legacy to Company Law Doctrine' in R Grantham and C Rickett, Corporate Personality in the Twentieth Century (Oxford: Hart, 1998); J MacLean, 'The Transnational Corporation in History: Lessons for Today?' (2004) 79 Indiana Law Journal 363.

${ }^{99}$ See Baxi, above n 87; Grear, above n 14; T Evans and AJ Ayers, 'In the Service of Power: The Global Political Economy of Citizenship and Human Rights' (2006) 10 Citizenship Studies 239-308. See also, for a general account of the 'meta-power' of global corporations: U Beck, Power in the Global Age (Cambridge: Polity Press 2005/6).

${ }^{100}$ A Norrie, Crime, Reason and History: A Critical Introduction to Criminal Law (London: Wiedenfeld and Nicolson, 1993).

${ }^{101}$ Ibid, at 8 .

102 At the same time, traditional 'customary rights' over land were effectively taken away in an extensive series of land enclosures (which provided a radical redefinition of property rights, displacing traditional social land rights with a forceful imposition of exclusory control directly linked to the replacement of traditional values by a powerful economic motive and capitalist competition: See EM Wood, The Origins of Capitalism (New York: The Monthly Press, 1999) at 67-94, cited by L Westra, 'Environmental Rights and Human Rights: The Final
} 
new 'objective' criminal laws deployed in this process was the production, Norrie argues, of a knowing individual subject who could be held fully responsible for his actions. P-E3 can be seen as, in a sense, a translation of the individualist ideology of the intellectual spokesmen of the period (the political economists) into a juridical subject perfectly matched to the needs of the emerging capitalist economic order. A knowing criminal legal subject constructed as a paradigmatically free individual fully able to calculate his own interests and fully responsible for his actions functioned - in part - to occlude from the question of legal responsibility any meaningful consideration of the often violently exclusive structural conditions of a rapidly capitalising society. ${ }^{103} \mathrm{P}-\mathrm{E} 3$, in this light, can be read as the figuration of a fully capitalistic legal subjectivity, one key function of which was to hold the newly constituted industrial poor fully responsible for their actions in a way that excised from view the structural causes of their socio-economic disadvantage. P-E3 thus performed a dual function. As a hypostatisation of homo economicus/homo juridicus it operated as a facilitative adjunct to the market, ${ }^{104}$ while simultaneously rendering individuals newly accountable to the strictures of capitalistic law. The construct, moreover, selectively (and incompletely) dis-embedded individuals from social circumstance and structural context, perhaps most especially those circumstances or contexts which might explain their actions or motivations on the basis of sociomaterial necessity. ${ }^{105}$ The legal subject thus produced and installed within the criminal law of the nineteenth century was a translation of the economically astute market-actor into the P-E3 criminal subject whose calculations of costs and benefits of crime and punishment were amply reflected in the development of utilitarian theories of deterrent punishment. ${ }^{106}$ The law reformers imagined a world populated by atomistic individuals operating freely in consensual relationships. Both market and law were conceived of as zones of rational exchange and neutrality between putatively equal male actors rather than as conflict-ridden sites of power struggle, yet despite the fact that '[i]ndividualistic ideological abstractions triumphed over bitter social realities ... the realities did not thereby obligingly disappear'. ${ }^{107}$

Norrie's analysis readily implies that the formation of liberal capitalism in the nineteenth century is aptly described as setting in motion 'the social process of exclusion and the concentration of modernity'. ${ }^{108}$ Law and legal theory played a crucial role in this process, systematically suppressing the gap between the violent inequalities of the emergent social relations and the smooth juridical production of social relations as putatively regularised, fully consensual and fully rational. ${ }^{109}$ As Norrie points out,

[i]n legal theory, the contradictions were kept at bay so long as the logic of abstract individualism and the myths of the political economy were adhered to. In theory, each

Enclosure Movement' in R Brownsword (ed) Global Governance and the Quest for Justice: Volume IV: Human Rights (Oxford: Hart Publishing, 2004) 107-119 at 107. At the same time new intensive capitalist agricultural methods were introduced and the old practise of tolerated pilferage was reconstituted as theft.

${ }^{103}$ This subject was hyper-rational in his ability to calculate costs and benefits, yet constructed 'at the cost of every social circumstance that actually brings individuals to reason and calculate in particular ways': Norrie, above $\mathrm{n} 100$ at 21.

${ }^{104}$ Norrie, above n 100, at 20.

105 Ibid.

106 Ibid, 18.

${ }^{107}$ Norrie, above, n 100, at 21.

${ }^{108}$ Santos, above $\mathrm{n} 92$ at 44.

${ }^{109}$ See, for more, the discussion in W. Chambliss and R. Seidman, Law, Order and Power (Reading, Massachusetts: Addison-Wesley Publishing Co, 1982). 
individual was the same as every other. All were potential possessors of property rights, all potential offenders against them. That in reality the possessors and the offenders came from different social classes constituted hardly a ripple on the millpond of theory. ${ }^{110}$

P-E3, placed in this light, functions as a 'caricature of the real person' ${ }^{111}$ The gap visible between PE3 and the complexity of socially-located, embodied, affectively complex human beings takes the form of 'both excess and lack, and becomes fully visible when people start legal proceedings' ${ }^{112}$ The excess is constituted by the law's ascription to the subject of an extreme rationalism. In terms of lack, P-E3 is complexly and incompletely disembodied, decontextualised, devoid of a complex emotional interiority - and its formulation as just such an entity is precisely what produces and reproduces its highly particularistic, patterned exclusions. P-E3 represents, to borrow the words of Schlag, a radical juridical 'emancipation of the self from its contexts' enabling the legal subject 'to be emancipated from all forces and influences other than law itself' ${ }^{113}$ P-E3, despite its naturalist gloss, is little more than 'metaphysical or calculating, self-interested being, conceived in an asocial way in a world whose sociality was no more than the coming together of individuals in a social contract... the law [knows]no real individuals, only their mystical abstractions' ${ }^{114}$

The P-E3 'natural person' is best conceptualised as an entity, a cipher - a socio-juridical projection, hypostatised in complex ways, but ultimately, a cipher that 'represents' (more accurately misrepresents) a notion of an underlying human person (itself a social construct in important and central respects). Arguably, it is the corporation, not the human being, which most closely approximates P-E3. The corporation is quintessentially disembodied and also the ultimate personification of market imperatives, presenting a form of subjectivity that perfectly fits, expresses, facilitates and perhaps even intensifies the priorities of capitalism itself. Examining law's ideological tilt towards the priority of P-E3 through the lens of personification ${ }^{115}$ underlines the corporation as the ultimate manifestation of P-E3. Again, the nineteenth century emerges as the decisive period, for this was the period in which the corporate form emerged when company law (like criminal law) was modernised.

Neocleous argues that 'what is at stake in the process of personification [are] the juridical as well as the socio-economic conditions which enable things to appear as non-human persons', ${ }^{116}$ and that personification has been decisive for the entrenchment of the social power of corporate capital. Indeed, P-E3 legal subjectivity and the mechanism of personification can be seen as complex but crucial conduits for the contemporary juridical dominance of the corporate form. ${ }^{117}$ Ironically, anticapitalist resistance to corporate power barely ever focuses on the corporate form despite its crucial role in lending the corporation particular advantages within the capitalist scheme of modern law.

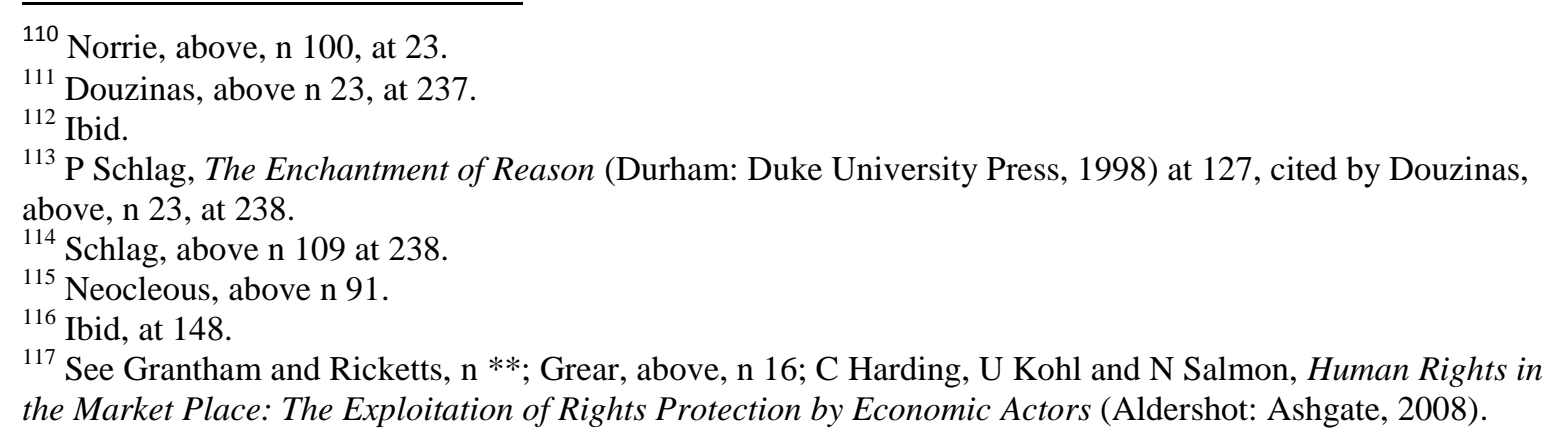


Significantly, the decision of the English House of Lords in Salomon v Salomon and Co Ltd, ${ }^{118}$ which as Neocleous suggests is the case that 'formally defined and recognised the private company as the legal form of capital', ${ }^{119}$ has been credited with establishing the constitutive preconditions of the corporate conglomerates which are now so dominant in the context of neoliberal globalisation. ${ }^{120}$ The historic significance of the Salomon case, therefore, for the intensification of capital accumulation was enormous. [It forged] a special legal subjectivity for capital, arising from the nature of capital itself'. ${ }^{121}$

Just as anti-capitalist resistance to corporate power has not focused closely enough, in general, upon the corporate form, so few arguments for extending legal subjectivity to new claimants locate their concerns against a critical engagement with the either the juridical dominance of the corporate form or the intimately related implications of P-E3 as the predominant form of legal subjectivity. Yet the corporation's emergence as 'a new and independent legal subject, every bit as real in law as the new personal subjects of the classic legal form .... ${ }^{122}$ has been decisive in its implications and is likely to remain so for all candidates for future legal subjectivity - including animals (which have been starkly instrumentalised since the advent of industrial and then corporate capitalism ${ }^{123}$ ) and the environment. (Indeed, it was recently suggested that corporate power is now the most significant block to progress on climate change goals. ${ }^{124}$ )

It seems important to emphasise, relatedly, that 'fit' with P-E3 is impossible for most, if not all, human beings (despite the fact that certain human beings (white, propertied males) clearly benefit from some kind of approximate correspondence with it). The critical accounts discussed here of the great reforming projects in commercial and criminal law shed important light on the ideological architecture of P-E3. The work of Neocleous and Norrie, taken together, suggestively indicates powerful linkages between the construction of the 'natural' P-E3 juridical subject and the way in which the corporation has emerged as a seamless match with the capitalistic commitments driving the socio-historical developments of the nineteenth century. This linkage is becomes explicit in Federman's account of the virtually simultaneous (or even paired)construction of corporate and criminal persons in America ${ }^{125}$ when corporations broke away from the state to take increasing advantage of the benefits of personification - including, notably, within constitutional rights discourse. ${ }^{126}$ Federman argues that '[f]or the first time in American constitutional law, the legal person takes shape not simply as a bearer of traditional English liberties, with all that implies

\footnotetext{
118 [1897] AC 22.

${ }^{119}$ Neocleous, above, $\mathrm{n} 91$ at 155.

${ }^{120}$ R. Grantham and C. Rickett, 'The Bookmaker's Legacy to Company Law Doctrine' in R. Grantham and C. Rickett, Corporate Personality in the Twentieth Century (Oxford: Hart Publishing, 1998) at 5.

${ }^{121}$ Neocleous, above, n 91at 155.

${ }^{122}$ Ibid, at 157, emphasis original.

${ }^{123}$ Nibert, above n 89.

${ }^{124}$ See, for example, the Al Jazeera report on the Rio+20 summit and the references therein to Friends of the Earth's report on corporate power - available at <http://www.aljazeera.com/programmes/insidestoryamericas/2012/06/201262211476935427.html> (Date of last access: $4^{\text {th }}$ July 2012 ).

${ }^{125}$ C. Federman, 'Constructing Kinds of Persons in 1886: Corporate and Criminal' (2003) 14 Law and Critique 167-189.

${ }^{126}$ This process is traced in detail by G.A Marks, 'The Personification of the Business Corporation in American Law' (1987) 54 The University of Chicago Law Review 1441-1483
} 
regarding personal autonomy, but as a corporate "person", who is not dissimilar to the bearer of traditional English liberties, and yet is structurally different ${ }^{\prime 27}$

Corporations have taken increasing power and priority within legal discourse, reaching even into the constitutional and human rights discourse paradigmatically aimed at the P-E3 construct of the 'human citizen' (and in the case of human rights, P-E2 (P-E3's complexly analogous construct)). ${ }^{128}$ The corporation fits the complex, incomplete disembodiment of P-E3 in a way that the vast majority of concrete, embodied, socially-situated human beings simply cannot. This difference alone gives the corporate form a distinct advantage over the living human being and over non-human animals and the environment, for P-E3 is particularly ill-suited to embodied, situated complexities. ${ }^{129}$ This poor fit becomes particularly pronounced, however, in relation to the 'others' of P-E3 and P-E2. PE3's detailed contours, as Naffine's analysis and numerous critical readings of the socio-historic and contemporary exclusions of legal subjectivity suggest, exclude all those human beings who do not or cannot fit its template: all those predictable 'outsiders' forming the traditional targets for hatespeech and/or discrimination of various kinds, reflecting well-rehearsed patterns of injustice long associated with Anglo-American citizenship. ${ }^{130}$

\footnotetext{
${ }^{127}$ Federman, above n 121, at 169, emphasis added. Federman identifies two cases, County of Santa Clara $v$ Southern Pacific Railroad ${ }^{127}$ and Ex parte Royall, (117 US 241 (1886)) as being the first emergence within US jurisprudence of the judicial classification and assessment of personalities invoking 'extra-legal signs of health and illness and productivity versus inefficiency' (at 168). The law, in a double move, categorised the corporation as the model American citizen while constructing the 'criminal' as the deviant posing a dark threat to private economic well-being and "the "privileged norms" of corporate personhood were "reinforced by the reaction against the transgressor"' (at 169, citing A Hunt and G Wickham, Foucault and Law: Towards a Sociology of Law as Governance (London: Pluto Press, 1998 [1994]), 95). The co-constitutive dynamic between corporate and criminal law/corporate and criminal subjectivity gives the corporation structural advantages in the avoidance of criminal liability for harms committed by it. Even today, there remains the sense in which, as Neocleous notes ' $[1]$ aw ... works in a way which is far more accommodating to corporate persons than human ones ... the corporation is a person when it comes to the advantages of law, but a 'non-person' when it comes to crimes seemingly committed by it ... the state personalizes capital, but doesn't punish it as a person. ... Capital has used the corporate form to its advantage by avoiding some of the most obvious disadvantages of being a legal person, namely responsibility for one's acts. A propos of attacks on 'welfare scroungers' and 'the idle poor', one might say that it is the corporation that has acquired plenty of rights but few responsibilities': Neocleous, above $\mathrm{n} 91$, at 163 . Indeed, it has been pointed out that 'crimes of economic domination' are often not even labelled as criminal by legal systems: R Quinney, Class, State and Crime: On the Theory and Practice of Criminal Justice (Longman: London, 1980).

${ }^{128}$ See, for more CJ Mayer, 'Personalising the Impersonal: Corporations and the Bill of Rights' (1990) 41 Hastings Law Journal 577; Baxi, n 87.

${ }^{129}$ As argued above - indeed, P-E3, at a metaphysical level, excludes embodiment in incomplete but significant ways. The ontology of P-E3 is entirely of a piece with disembodying Western philosophical foundations (such those of Cartesianism and Kantianism) still reflected in the writings of those trained in philosophy who are 'always at some distance from corporeal matters, who try in that disembodied way to demarcate bodily terrains: they invariably miss the body or, worse, write against it.' J Butler, Bodies that Matter: On the Discursive Limits of Sex (London: Routledge, 1993), Preface at $i x$.

${ }^{130}$ The nineteenth century is particularly significant in respect of the structural dynamics associated with the production of P-E3's 'others':

All assertions of ... rights by the groups and classes excluded from citizenship, women, blacks, workers or political and social reformers, were dismissed as selfish attacks against the common good and the democratic will. This was the era of state and empire-building, of utilitarianism and social engineering, the time of emergence of nationalism, racism and sexism. It was not that these ideas and practices were unknown before the nineteenth century but they now became theorised and respectable elements of European culture (Douzinas, above n 23, at 109-110).
} 
The continuity between P-E3 and the corporate form of capital reflexively emphasises the constructed and highly selective nature of the 'natural person' putatively represented by P-E3 and PE2 (to a more muted extent). This powerfully naturalised construct presents, it is suggested, considerable challenges for anyone concerned to see legal subjectivity become genuinely more inclusive and has a limited potential to transcend its constructed naturalism in order to respond to the complexities, mutations, hybridities and multiplicities confronting law in the twenty-first century.

One implication of this analysis is that those who seek to extend the ambit of legal subjectivity to embrace putative new forms of claimant should advert with great care to P-E3's dominance. This is especially important in a context where capitalism's uncanny ability continuously and reflexively to adopt the guise and languages of its critiques and counter-values presents a genuine problem. For those seeking rights for animals and nature, for example, it would be salutary to reflect upon the fact that the realisation of an order of international human rights for embodied vulnerable human beings has been rendered dependent upon the prior recognition of an order of rights for global capital $^{131}$ - and to reflect upon the power of the closures implicated by that reality. Baxi argues that any serious sociological reading of international human rights law now forces the conclusion that international human rights have been 'critically appropriated by global capital', ${ }^{132}$ while Evans and Ayers conclude that human rights have been effectively 'co-opted' by a forcible distortion 'in support of processes associated with capitalist globalisation'. ${ }^{133}$ This is a bleak assessment. It is further supported by those accounts of 'sustainable development' and (its intended critique) 'sustainability' discourse (even within progressive multi-level governance settings) which reveal the capture of green agendas by the ideological and procedural dominance of corporate actors. ${ }^{134}$ Such dangers, arguably inherently linked to the dominance of P-E3, both as an ideological and a functional matter, should be borne in mind in debates concerning the extension of legal subjectivity. In particular, attention should be paid to the way in which P-E3's constructed naturalism disguises its reality as a constructus.

\section{Conclusion}

This argument has underlined the constructed nature of all three templates of law's entity/person in order to underline the critical advantages of emphasising their 'artificiality' over continuing to accept the constructed naturalism of PE-2 and P-E3. There is a productive (and critically satisfying) sense in which law's conception of the 'legal person' is best understood as E-E1, precisely because of its explicit emphasis upon its function as a system referent. Emphasising the necessary 'artificiality' of law's 'entity' as a constructus, as E-E1 does, headlines, in a sense, law's limitations in a way that allows the messy materiality subtending and exceeding law's categories of reference to come into fuller view both as a theoretical and as an ethical matter. E-E1, unlike P-E3 and P-E2, is explicit about its artificiality. While doubts can be cast upon E-E1's ability to remain empty, the construct offers the best currently available candidate-conception of law's entity upon which to found a responsive,

\footnotetext{
${ }^{131}$ Baxi, above n 87.

${ }^{132}$ U Baxi, The Future of Human Rights (Oxford: Oxford University Press, 2002) at 147.

${ }^{133}$ Evans and Ayers, above, n 99, abstract, emphasis added.

${ }^{134}$ See, for example, A Rowell, Green Backlash: The Global Subversion of the Environmental Movement (London: Routledge, 1996).
} 
suitably complexity-sensitive account of legal subjectivity. First, E-E1 is highly plastic: Its very formality and/or agnosticism, as Naffine points out, means that it can be taken to 'stand for' just about anything. Given the dynamic complexities, uncertainties and rapidly multiplying hybrid forms inhabiting the socio-materiality within which law performs its coordinating role, such plasticity is not only useful, but will become increasingly indispensable. Secondly, E-E1 has the virtue of already being in existence as a concept deployed within law and legal theory. Suitably rehabilitated, it is, therefore, not alien to the courts. Thirdly, because of its very formality and artificiality as an explicit constructus, E-E1 resists, to some extent, the obfuscating traction of the idea of 'natural personhood' evoked by P-E2 and P-E3. Simultaneously, because the language of 'legal entity' can be deployed to replace the language of 'legal personhood' it may be possible to shift the semantic resonance of law's referents away from 'persons' and 'humans' towards a wider range of candidates for legal subjectivity. This potentially allows E-E1 to offer more to theories of legal subjectivity than the truncated anthropomorphism so troubling to many and inherent to P-E2 and P-E3. Fourthly, emphasising E-E1's status as constructus (something always implicit in the term 'legal entity') has the advantage of pointing, almost ineluctably, towards law's living excess which emerges dynamically from the complex, organic, shifting, embodied, mutable and situated realities of the socio-material, spatio-temporal aliveness woven through, beyond and beneath law. Finally, while E-E1 will be forced, as argued above, to materialise - it is possible that by foregrounding E-E1 explicitly against a critique of P-E2 and P-E3 we can invite legal theorists to engage with vital questions concerning the form of E-E1's materialisation so fundamental to the search for eco-humane justice in a complex age. 